\title{
Direct modelling of mouthguard pattern using modified impression tray
}

\section{Metoda bezpośredniego modelowania wzorca ochraniacza wewnątrzustnego na zmodyfikowanej lyżce wyciskowej}

\author{
Katarzyna Mańka-Malara1, Dominika Gawlak', Robert Lojszczyk ${ }^{2}$, \\ Maciej Trzaskowski', Elżbieta Mierzwińska-Nastalska ${ }^{1}$ \\ ${ }^{1}$ Katedra Protetyki Stomatologicznej, Warszawski Uniwersytet Medyczny \\ Department of Prosthodontics, Medical University of Warsaw \\ Head: prof. dr hab. n. med. Elżbieta Mierzwińska-Nastalska \\ ${ }^{2}$ Zakład Propedeutyki i Profilaktyki Stomatologicznej, Warszawski Uniwersytet Medyczny \\ Department of Propaedeutics and Dental Prophylaxis, Medical University of Warsaw \\ Head: dr hab. n. med. Leopold Wagner
}

KEY WORDS:

mouthguards, injury prevention, occlusal splints

\section{Summary}

Introduction. Ethylene-vinyl-acetate (EVA) custom-made mouthguards - the most common type - have one significant drawback - during fabrication the material is stretched and thinned. Many authors describe possible solutions to this side effect. However, other materials are currently available that enable manufacturing of mouthguards of predictable size. Although they have appropriate shock-absorbing properties, the laboratory procedure is more complex.

Aim of the study. To propose a new, simplified method of custom-made mouthguards formation.

Material and methods. Sixty custom-made mouthguards, prepared for 30 athletes, were assessed. They were fabricated on the basis of directly modelled mouthguard pattern. Modified double-arch impression on adapted upper arch tray was taken and then silicone pattern was adjusted. Thirty mouthguards were fabricated using Impak material (Vernon - Benshoff Comp., USA) and another thirty using Corflex
HASŁA INDEKSOWE:

ochraniacze wewnątrzustne, profilaktyka urazów, szyny okluzyjne

\section{Streszczenie}

Wstęp. Najczesściej stosowane indywidualne ochraniacze wykonane z etyleno-octanu-winylu (EVA) maja istotna wade - podczas formowania materiat ulega rozciagnięciu $i$ wycienieniu. Wielu autorów opisuje możliwe rozwiązania tego efektu ubocznego. Obecnie sa dostęne materiaty umożliwiajace wykonanie ochraniacza wewnatrzustnego o przewidywalnych wymiarach. Jednak, pomimo odpowiednich wtaściwości pochtaniajacych energie, procedura wykonawstwa laboratoryjnego jest bardziej złożona.

Cel pracy. Celem pracy byto zaproponowanie uproszczonej procedury wykonania ochraniaczy indywidualnych.

Material $i$ metody. $W$ badaniu oceniono 60 indywidualnych ochraniaczy wewnątrzustnych wykonanych $z$ uzyciem metody bezpośredniego modelowania wzorca szyny ochronnej dla 30 sportowców. Wykonano zmodyfikowany wycisk dwuszczękowy na dostosowanej tyżce wyciskowej dla szczęki a nastęnie dostosowano silikonowy 
Orthodontic material (Pressing Dental, Italy). All protective splints were evaluated clinically.

Results. All assessed appliances were rated as correct, meeting the quality criteria for custommade mouthguards. Relations between the maxilla and the mandible were correct, the occlusal contacts were optimal and evenly distributed. Protective splints did not require adjustments of the insertion track, and had optimal retention, fit and correct dimensions.

Conclusions. Direct modelling of mouthguard pattern using modified impression tray is easy to perform, giving the opportunity to verify and correct the mouthguard pattern at a preliminary stage without introducing significant adjustments to the final splint. This method can be successfully used clinically.

\section{Introduction}

In manufacturing of custom-made mouthguards, which are recommended in various sport disciplines, thermoforming, conventional flasking technique and thermal injection methods are used.1-8 Vacuumforming of custom protective splint with heated ethylene-vinyl-acetate (EVA) is the method most commonly described in the literature and testedis. The problem that is associated with this method of mouthguard formation is difficulty in obtaining the optimal thickness on all surfaces of the guard, so that proper protection against the effects of injuries is obtained. ${ }^{1,9-13}$ After plastification in high temperature, the material is stretched and thinned during forming. ${ }^{14,15}$ In the literature, the loss of up to $25 \%$ of the thickness on the occlusal surface and $50 \%$ on the labial surface was reported, resulting in the loss of the ability of the guard to weaken the impact. ${ }^{16}$ Currently, many authors publish recommendations on proper formation wzorzec. Wykonano 30 ochraniaczy z materiatu Impak (Vernon - Benshoff Comp., USA) i 30 z materiatu Corflex Orthodontic (Pressing Dental, Włochy). Wszystkie ochraniacze poddano ocenie kliniczniej.

Wyniki. Wszystkie wykonane ochraniacze zostaty ocenione jako prawidtowe $i$ spetniajace kryteria indywidualnej szyny ochronnej. Relacje pomiędzy szczęka a żuchwa byly prawidlowe, a uzyskane kontakty $w$ okluzji optymalne i równomierne. Szyny nie wymagaty korekt toru wprowadzania, a także cechowaty się optymalną retencja, dopasowaniem i prawidlowymi wymiarami.

Wnioski. Pobranie wycisku na zmodyfikowanej tyżce wyciskowej jest proste w wykonaniu, pozwala wstęnie zweryfikować $i$ skorygować wzorzec ochraniacza bez wprowadzania istotnych zmian w gotowym uzupetnieniu. Metoda ta może być z powodzeniem stosowana klinicznie.

\section{Wstęp}

W wykonawstwie indywidualnych ochraniaczy wewnątrzustnych, stosowanych w różnych dyscyplinach sportowych wykorzystywana jest technika formowania wgłębnego, metoda tradycyjnej polimeryzacji w puszce i metoda wtrysku termicznego. ${ }^{1-8} \mathrm{~W}$ piśmiennictwie najczęściej opisywane i badane jest przygotowywanie szyny ochronnej z etylenooctanu winylu - EVA. Problemem związanym z tym sposobem przygotowania ochronnej szyny okluzyjnej jest uzyskanie optymalnej grubości na wszystkich powierzchniach zębów, koniecznej $\mathrm{w}$ celu zapewnienia właściwego zabezpieczenia zębów przed skutkami urazów. 1,9-13 W trakcie tłoczenia, wykonywanego po uplastycznieniu w wysokiej temperaturze, materiał ulega rozciągnięciu i wycienieniu. ${ }^{14,15} \mathrm{~W}$ piśmiennictwie opisywano utratę nawet do $25 \%$ grubości ochraniacza na powierzchni okluzyjnej i $50 \%$ na powierzchni wargowej, co skutkowało utratą jego zdolności tłumienia siły 
of vacuum-formed and pressure-formed mouthguards, searching for suitable location of the model, as well as the proper way of warming the plates of the material. ${ }^{1,2,5,9-13}$ However, this method still seems to be burdened with a lack of predictability of the dimensions of the final product.

The formation of a custom-made mouthguard using traditional flasking technique or by using thermal injection is preceded by modelling the wax shape of a splint on a plaster model by a dental technician. ${ }^{2,7,8}$ By pressing and curing the material, which replaces the wax, or high pressure injection, accurate contact to the model is achieved, and the ultimate mouthguard's dimensions are such as designed. In the thermal injection method, maintaining high pressure until thermopolymer cools, also reduces linear shrinkage. ${ }^{17}$ Mouthguards prepared using Impak material (Vernon - Benshoff Comp., USA) - traditional flasking technique, or Corflex Orthodontic (PressingDental, Italy) injection moulding - are positively evaluated by users and doctors. ${ }^{2,7,8}$ In addition, these materials have suitable properties of cushioning the energy of impact. ${ }^{18}$ In the classic protocol of custom-made mouthguards created using this methods, on the first appointment, after thorough clinical examination, impressions and the facebow transfer are taken. Then, the model is placed in the articulator.

The search for a simplified procedure, optimal relation between maxilla and mandible and maximum teeth contact in custom-made mouthguard, prompted the authors of this study to develop a method of direct modelling of mouthguards using a modified impression tray. The use of double-arch impression is not a novel solution in prosthodontics - this method has been successfully used for instance in the BPS method - Biofunctional Prosthetic System (Ivoclar Vivadent, Liechtenstein). ${ }^{19,20}$ uderzenia. ${ }^{16}$ Obecnie liczni autorzy publikują zalecenia dotyczące właściwego wykonania szyny ochronnej formowanej wgłębnie, szukając odpowiedniej lokalizacji umieszczenia modelu a także właściwego sposobu rozgrzewania płytek przed formowaniem, ${ }^{1,2,5,9-13}$ jednakże metoda ta nadal wydaje się być obarczona pewnym brakiem przewidywalności wymiarów gotowej szyny.

Wykonanie ochraniacza indywidualnego za pomocą tradycyjnej polimeryzacji lub przy użyciu metody wtrysku termicznego poprzedzone jest wymodelowaniem kształtu ochraniacza z wosku przez technika dentystycznego na gipsowym modelu. ${ }^{2,7,8}$ Poprzez prasowanie materiału w puszce polimeryzacyjnej lub wtłaczanie go pod dużym ciśnieniem uzyskuje się dokładne przyleganie szyny do podłoża, a wymiary gotowej szyny zgodne są z zaprojektowanymi. W metodzie wtrysku termicznego utrzymywanie wysokiego ciśnienia w urządzeniu do pełnego ostygnięcia termopolimeru, wpływa na zmniejszenie jego kurczliwości liniowej. ${ }^{17}$ Ochraniacze wykonane $\mathrm{z}$ materiału Impak - tradycyjna polimeryzacja - i Corflex Orthodontic - metoda wtrysku termicznego - są pozytywnie ocenianie przez użytkowników i lekarzy. ${ }^{2,7,8}$ Dodatkowo materiały te mają odpowiednie własności tłumienia energii uderzenia. ${ }^{18} \mathrm{~W}$ tradycyjnym protokole wykonania ochraniaczy indywidualnych $\mathrm{z}$ tych materiałów, na pierwszej wizycie po badaniu klinicznym, pobierane są wyciski i wykonywana rejestracja łukiem twarzowym, a model zębów pacjenta umieszczany jest przed kolejnymi etapami laboratoryjnymi w artykulatorze.

Poszukiwanie optymalnej relacji żuchwy w stosunku do szczęki w indywidualnym ochraniaczu skłoniło autorów tego badania do opracowania metody indywidualnego wewnątrzustnego modelowania wzorca ochraniacza, w postaci wycisku dwuszczękowego na zmodyfikowanej łyżce wyciskowej. Zastosowanie dwuszczękowego wycisku 


\section{Aim}

The aim of this study was to develop a new method of preparation of custom-made mouthguards.

\section{Material and Methods}

The study involved assessing 60 custommade mouthguards, prepared for 30 athletes, using direct modelling of the mouthguard pattern method. The number of male and female participants was the same. All participants professionally practised sport disciplines in which mouthguards are used. They were familiar with the planned course of the study and gave their informed consent. Detailed medical interview was conducted and clinical dental examination was performed with special emphasis on the evaluation of the masticatory system - the examination of masticatory muscles and temporomandibular joint.

A modified impression tray for the maxilla was used, in whichmost of the occlusal surface was eliminated (Fig. 1), leaving its fragment in the incisal area. Appropriate size of the tray was chosen, leaving space for the impression material and enabling partial closure of the mouth. Before the impression is taken, the ability to close the mouth to the desired height - with simultaneous control of movement of the

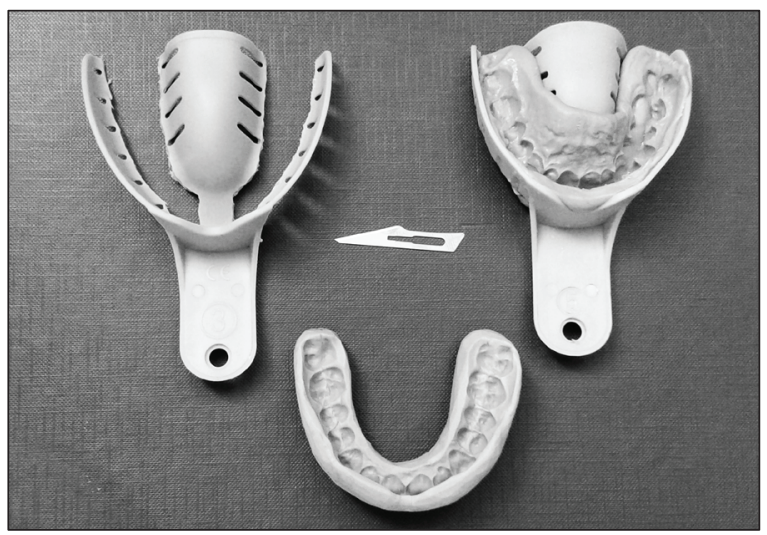

Fig. 1. Modified impression tray.

Ryc. 1. Zmodyfikowana tyżka wyciskowa. nie jest $\mathrm{w}$ protetyce stomatologicznej rozwiązaniem nowym - taka metoda jest z powodzeniem stosowana $\mathrm{w}$ metodzie BPS Biofunkcjonalny System Protetyczny. ${ }^{19,20}$

\section{Cel pracy}

Celem pracy było zaproponowanie uproszczonej procedury wykonania ochraniaczy indywidualnych.

\section{Material i metody}

W badaniu oceniono 60 indywidualnych ochraniaczy wewnątrzustnych wykonanych z użyciem metody bezpośredniego modelowania wzorca szyny ochronnej dla 30 sportowców. Liczba kobiet i mężczyzn była równa. Wszyscy uczestnicy zawodniczo trenowali dyscypliny, w których zastosowanie mają ochraniacze wewnątrzustne. Badani zapoznali się z planowanym przebiegiem badania i wyrazili zgodę na udział w nim. Przeprowadzono szczegółowy wywiad ogólny i specjalistyczny oraz wykonano kliniczne badanie stomatologiczne, ze szczególnym naciskiem na ocenę układu ruchowego narządu żucia - badanie mięśni żucia oraz badanie stawu skroniowo-żuchwowego.

Wykorzystano modyfikację łyżki wyciskowej - polegającą na pozbawieniu plastikowej łyżki do wycisków szczęki większości powierzchni okluzyjnej (ryc. 1), z pozostawieniem fragmentu w okolicy zębów siecznych. Dobrano odpowiednią wielkość łyżki, tak aby pokrywała całość łuku zębowego szczęki z pozostawieniem miejsca na masę wyciskową oraz nie utrudniała przymknięcia ust. Przed pobraniem wycisku zweryfikowano możliwość przymknięcia ust do pożądanej wysokości z jednoczesną kontrolą ruchu żuchwy wskazane jest przećwiczenie $\mathrm{z}$ pacjentem reakcji na polecenie zatrzymania ruchu oraz reakcji na delikatne prowadzenie przez lekarza. 


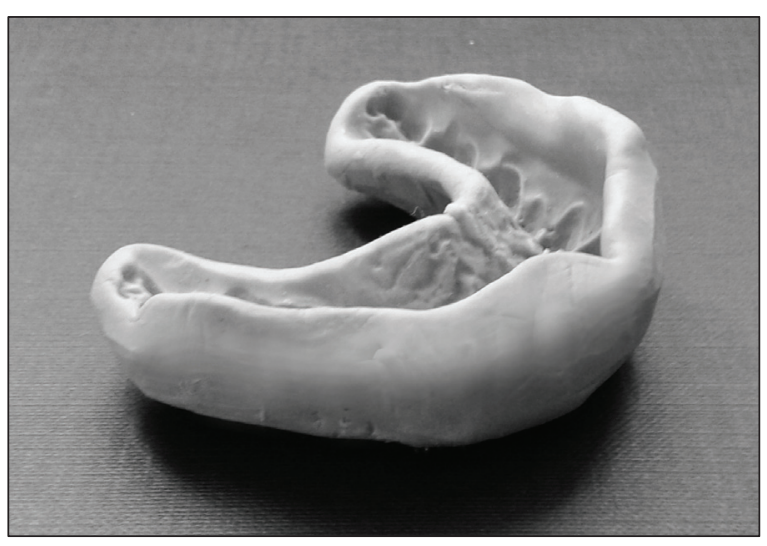

Fig. 2. Mouthguard pattern.

Ryc. 2. Wymodelowany wzorzec indywidualnego ochraniacza wewnątrzustnego.

mandible - is verified; it is important to practise with the patient his/her reaction to the command to stop movement and reaction to dentist's gentle guiding. Patient's jaw should not move to the side or forward. The impressions were taken using Zeta Plus (Zhermack). When the impression tray with material is being placed in the oral cavity, dentist's index fingers should be placed under the occlusal surfaces, where the impression material is not supported, so that full recording of the dental arches is achieved. The patient slowly closes the mouth under dentist's supervision. The part of the impression tray in the anterior region additionally prevents the complete closure, which would result in a lack of space for the mouthguard material between the arches. The impression material can also be moved with a finger to the vestibule of the oral cavity to achieve full and accurate representation of the dental arch. By using a modified tray the impression of the maxillary teeth and alveolar processes is recorded, as well as the proper relation of maxillary and mandibular teeth in the prepared splint. The impression was released from the tray after setting. The excess material was cut off with a scalpel and the final pattern of the mouthguard was shaped (Fig. 2). Then the correct thickness of the pattern splint (about $3 \mathrm{~mm}$ on the outer
Pacjent nie powinien przemieszczać żuchwy $\mathrm{w}$ bok lub doprzednio. Wycisk pobierano $\mathrm{z}$ zastosowaniem masy Zeta Plus (Zhermack). Podczas wprowadzania łyżki wyciskowej do jamy ustnej pacjenta, wskazujące palce lekarza powinny znajdować się pod powierzchniami okluzyjnymi, gdzie masa wyciskowa pozbawiona jest podparcia, aby możliwe było pełne odwzorowanie łuków zębowych. Po wprowadzeniu łyżki pacjent pod kontrolą lekarza przymyka usta. Fragment łyżki w odcinku przednim chroni przed całkowitym zamknięciem ust - skutkowałoby ono brakiem miejsca na materiał ochraniacza w przestrzeni między łukami zębowymi. Masa wyciskowa może zostać dodatkowo podprowadzona palcem w przedsionku jamy ustnej w celu osiągnięcia pełnego i wysokiego odwzorowania łuku zębowego. Zastosowanie zmodyfikowanej łyżki wyciskowej pozwoliło na rejestrację jednoczasowo wycisku zębów i wyrostków zębodołowych szczęki oraz prawidłowego kontaktu zębów szczęki i żuchwy w planowanym ochraniaczu. Po związaniu masy wycisk uwalniano, nadmiary masy odcinano za pomocą skalpela, nadając jej kształt wzorca ochraniacza wewnątrzustnego (ryc. 2). Wzorzec ochraniacza sprawdzany był za pomocą grubościomierza $\mathrm{w}$ celu weryfikacji uzyskania prawidłowej grubości szyny (ok. $3 \mathrm{~mm}$ na powierzchni zewnętrznej). ${ }^{21}$ Wymodelowany wzorzec ochraniacza oceniany był wewnątrzustnie u pacjenta - sprawdzano prawidłowość relacji szczęki i żuchwy, pokrycie łuków zębowych i komfort pacjenta w uzyskanej relacji.

Dla każdego pacjenta wykonano dwa indywidualne ochraniacze wewnątrzustne - z materiału Impak (Vernon - Benshoff Comp., USA) oraz Corflex Orthodontic (PressingDental, Włochy). W celu otrzymania szyn ochronnych z materiału Impak wymodelowany wzorzec ochraniacza umieszczano w wypełnionej gipsem puszce polimeryzacyjnej. Po związaniu gipsu materiał silikonowy usuwano a w 
surface) was checked, using thickness gauge. ${ }^{21}$ The pattern was verified in the oral cavity of the patient - the correct relation between maxilla and mandible, the cover of dental arches, teeth contact and the comfort of the user in the obtained relationship were checked.

There were two custom-made mouthguards prepared for each athlete - one made of Impak material (Vernon - Benshoff Comp., USA) and the second made of Corflex Orthodontic (Pressing Dental, Italy. In order to obtain mouthguards made of Impak, the pattern was placed in flask filled with plaster. After plaster had set, silicone material was removed and replaced with the mixed Impak material, pressed and cured according to manufacturer's recommendations. After removing from flask, the splint was cleaned, finished and polished in dental laboratory. To prepare a mouthguard from Corflex Orthodontic, the pattern was placed in the flask filled with plaster, leaving sprue and outlet channel. After plaster had set, the silicone was removed and then the material was pressure-injected in Mg-Newpress device. After cooling the mouthguard was removed, finished and polished.

Custom-made mouthguards were evaluated when they were given to the athletes and during the follow-up visits. The verification included the correctness of the laboratory formation, the cover of dental arches, teeth contact, the shape, thickness and smoothness of the protective splint, retention, ease of placing in the oral cavity and maxilla-mandible relationship in the mouthguard.

\section{Results}

All assessed appliances were rated as correct since they met the quality criteria of custom-made mouthguards. Despite the lack of registration with facebow, obtained relations between the maxilla and the mandible were correct, and the occlusal contacts were optimal jego miejscu umieszczano materiał Impak, po zmieszaniu odpowiedniej ilości proszku i płynu. Po sprasowaniu i polimeryzacji według zaleceń producenta ochraniacz uwalniano z puszki, oczyszczano, opracowywano i polerowano $\mathrm{w}$ pracowni techniki dentystycznej. W celu wykonania ochraniacza $\mathrm{z}$ materiału Corflex Orthodontic wzorzec szyny ochronnej umieszczany był w puszce, wypełnionej następnie gipsem, z pozostawieniem kanałów wlewowych. Po związaniu gipsu silikon usuwano, a materiał wprowadzano techniką wtrysku termicznego w urządzeniu Mg-Newpress. Po całkowitym schłodzeniu opracowywano i polerowano gotowy ochraniacz indywidualny.

Wykonane ochraniacze indywidualne oceniano podczas wizyty, na której oddawane były do użytkowania przez sportowców oraz wizyty kontrolnej. Weryfikowano prawidłowość wykonania gotowej szyny, pokrycie łuków zębowych, ukształtowanie ochraniacza, retencję, łatwość wprowadzania oraz relację szczęki do żuchwy w szynie ochronnej.

\section{Wyniki}

Wszystkie wykonane ochraniacze zostały ocenione jako prawidłowe i spełniające kryteria indywidualnej szyny ochronnej. Pomimo braku rejestracji z użyciem łuku twarzowego relacje pomiędzy szczęką a żuchwą były prawidłowe, a uzyskane kontakty w okluzji optymalne i równomierne. Szyny nie wymagały korekt toru wprowadzania, a także cechowały się optymalną retencją, dopasowaniem i prawidłowymi wymiarami. Tabela 1 zawiera klinicznie istotne różnice, występujące pomiędzy ochraniaczami indywidualnymi wykonywanymi z materiałów Impak i Corflex Orthodontic.

Pobranie wycisku na zmodyfikowanej łyżce wyciskowej jest proste w wykonaniu, a docięcie silikonowego wzorca ochraniacza nie jest 
Ta b $1 \mathrm{e} 1$. Comparison of custom-made mouthguards made with Impak and Corflex Orthodontic material

\begin{tabular}{|l|l|}
\hline \multicolumn{1}{|c|}{ Impak Mouthguards } & \multicolumn{1}{c|}{ Corflex Orthodontic Mouthguards } \\
\hline Hybrid acrylic material & Vinyl resin \\
\hline Traditional flasking technique & Injection moulding technique \\
\hline Transparent material & Different colours of the material \\
\hline $\begin{array}{l}\text { Possible consistency adaptation by change of the } \\
\text { power to liquid ratio }\end{array}$ & $\begin{array}{l}\text { Capsules of material with defined proportions of } \\
\text { components }\end{array}$ \\
\hline
\end{tabular}

Ta b le 2. Comparison of methods used for mouthguard fabrication - traditional and with the use of mouthguard pattern

\begin{tabular}{|l|c|c|}
\hline \multicolumn{1}{|c|}{ Stage } & $\begin{array}{c}\text { Traditional } \\
\text { method }\end{array}$ & $\begin{array}{c}\text { Method with } \\
\text { mouthguard pattern }\end{array}$ \\
\hline Thorough examination of the patient & + & + \\
\hline Selection of standard impression tray & + & - \\
\hline Selection of modified impression tray & - & + \\
\hline Alginate impression of maxilla and mandible & + & + \\
\hline Modified double-arch impression tray & - & - \\
\hline Bite registration & + & - \\
\hline Registration with facebow & + & - \\
\hline Gypsum cast placement in articulator & + & + \\
\hline Modelling of mouthguard shape with the wax & + & + \\
\hline Adjusting the silicone mouthguard pattern & - & + \\
\hline $\begin{array}{l}\text { Flasking and mouthguard formation according } \\
\text { to manufacturer's recommendations }\end{array}$ & + & + \\
\hline Adjustment of final mouthguard & + & + \\
\hline
\end{tabular}

and evenly distributed. Protective splints did not require adjustments of the insertion track, and they also had optimal retention, fit and correct dimensions. Table 1 shows clinically important differences between custom-made mouthguards made with Impak and Corflex Orthodontic material.

Impression on a modified tray is easy to take and cutting silicone mouthguard pattern to shape is not time consuming. Application czasochłonne. Zastosowanie modelu z silikonu zamiast wymodelowania $\mathrm{z}$ wosku nie spowodowało konieczności modyfikacji dalszych etapów laboratoryjnych, a gotowe ochraniacze indywidualne mogły być wykonane zgodnie $\mathrm{z}$ zaleceniami producentów materiałów. Porównanie tradycyjnej metody $z$ metodą modelowania wzorca ochraniacza zawarto $\mathrm{w}$ tabeli 2 . 
of the silicone pattern instead of the wax one did not result in the need to modify the later stages of laboratory formation and thus mouthguards could be made in accordance with the recommendations of manufacturers. Comparison of methods of mouthguard fabrication - traditional and with the use of mouthguard pattern is included in Table 2.

\section{Discussion}

Mouthguard is a modification of flexible intraoral occlusal splint. In prosthodontics soft splints made by pressure-forming in Erkopresstype devices are used for temporary wear before the final occlusal splint is presented to the patient, or as a lining for a hard splint. ${ }^{22}$ However, such appliances are short-term only because their long-term use may lead to occlusal disturbances, displacements of teeth, formation of premature contacts or masticatory muscles overload. ${ }^{23}$ According to Glass et al. ${ }^{24}$ mouthguards should be regarded as therapeutic appliances. The dentist should periodically evaluate the condition of the protective splint and exclude the possibility of its iatrogenic impact. Studies indicate, however, that as many as $20 \%$ of mouthguard users do not replace the protective splint, ${ }^{25}$ nor do they present it for dentist's evaluation. Thus, the intraoral appliance should be designed and constructed in the most optimal way - ensuring balanced occlusal contact and lack of overload, and patients should be properly educated. Murakami et al. ${ }^{26}$ indicate that patients with temporomandibular disorders should not use mouthguards with occlusal surface thickness higher than $3 \mathrm{~mm}$. Kostrzewa-Janicka et al. ${ }^{27}$ proposed a model based on facial morphology analysis, to determinate for each patient individually the degree of mandibular abduction at which the patient has minimum bite force. This method is not used in standard custommade mouthguard fabrication. A recent study

\section{Dyskusja}

Ochraniacz wewnątrzustny jest modyfikacją elastycznej szyny okluzyjnej. $\mathrm{W}$ protetyce stomatologicznej miękkie szyny wykonywane metodą formowania wgłębnego wykonywane w urządzaniu typu Erkopress stosowane są do czasowego użytkowania przed oddaniem właściwej szyny zgryzowej lub jako podbudowa twardej szyny.22 Tego rodzaju uzupełnienia są zalecane jednak jedynie na krótki okres czasu, ponieważ ich długoczasowe użytkowanie może doprowadzać do zaburzeń w okluzji poprzez wysuwanie pojedynczych zębów, powstawanie przedwczesnych kontaktów, a także przeciążenie mięśni. ${ }^{23}$ Według Glass'a i wsp. ${ }^{24}$ ochraniacz wewnątrzustny powinien być postrzegany jako urządzenie terapeutyczne. Lekarz dentysta podczas regularnych wizyt kontrolnych powinien oceniać zarówno stan uzupełnienia, jak i wykluczać jego działanie jatrogenne. Badania jednak wskazują, że aż 20\% użytkowników ochraniaczy nigdy nie wymienia stosowanej szyny ochronnej, ${ }^{25}$ a tym bardziej nie poddaje jej ocenie lekarza dentysty. Oddawane do użytkowania uzupełnienie powinno być więc zaprojektowane i wykonane w sposób możliwie najbardziej optymalny, zapewniający równomierny kontakt w okluzji, brak przeciążeń, a pacjenci odpowiednio edukowani. Murakami i wsp. ${ }^{26}$ podają że pacjenci $\mathrm{z}$ zaburzeniami stawu skroniowo-żuchwowego nie powinni użytkować ochraniacza wewnątrzustnego o powierzchni okluzyjnej podniesionej powyżej $3 \mathrm{~mm}$. Kostrzewa-Janicka i wsp. ${ }^{27} \mathrm{za}-$ proponowali wzór opierający się na zbiorczej analizie parametrów budowy czaszki pozwalający na określenie indywidualnie dla każdego pacjenta stopnia odwodzenia żuchwy, przy którym występuje minimum siły zgryzowej. Sposób ten nie jest jednak wykorzystywany w codziennej praktyce wykonania ochraniaczy wewnątrzustnych. Ostatnie badania Verissimo 
by Verissimo et al. ${ }^{28}$ emphasizes that achieving balanced occlusion and maximum teeth contact allow obtaining proper stress distribution on impact through appropriate stabilization of the mouthguard.

\section{Conlusions}

Direct modelling of mouthguard pattern using modified impression tray is easy to perform. It gives the opportunity to verify and correct the mouthguard pattern at the preliminary stage without introducing significant adjustments in the final splint. Simplified procedure of custom-made mouthguard formation can be successfully used clinically. i wsp. ${ }^{28}$ podkreślają, że dążenie do uzyskania zrównoważonej okluzji i maksymalnych kontaktów z zębami pozwalają na uzyskanie właściwego rozkładu naprężeń podczas uderzenia poprzez odpowiednią stabilizację szyny ochronnej.

\section{Wnioski}

Proponowana technika bezpośredniego modelowania wzorca ochraniacza jest prosta w wykonaniu. Daje możliwość wstępnej weryfikacji wymodelowanego wzorca szyny ochronnej bez konieczności wprowadzania znaczących korekt w gotowym uzupełnieniu. Uproszczona procedura wykonania ochraniacza indywidualnego z zastosowaniem techniki bezpośredniego modelowania wewnątrzustnego może być z powodzeniem stosowana kliniczne.

\section{References / Piśmiennictwo}

1. Mizuhashi F, Koide K: Formation of vacuum-formed and pressure-formed mouthguards. Dent Traumatol 2017; 33: 295-299.

2. Mańka-Malara K, Gawlak D: The comparison of mouthguards used in combat sports. Dent Med Probl 2013; 50: 205-209.

3. Mizuhashi F, Koide K: Formation of vacuumformed and pressure-formed mouthguards. Dent Traumatol 2017; 33: 295-299.

4. Gawlak D, Mańka-Malara K, MierzwińskaNastalska E, Roman G, Kamiński T, Łuniewska $M$ : A comparison of impact force reduction by polymer materials used for mouthguard fabrication. Acta Bio 2017; 19: 89-95.

5. Fukosawa S, Churei H, Chowdhury $R U$, Shirako T, Shahrin S, Shrestha A, Wada T, Uo $M$, Takahashi H, Ueno T: Difference among shock-absorbing capabilities of mouthguard materials. Dent Traumatol 2017; 32: 474-479.

6. Bochnig MS, Oh MJ, Nagel T, Ziegler F,
Brinkmann PGJ: Comparison of the shock absorption capacities of different mouthguards. Dent Traumatol 2017; 33: 205-213.

7. Gawlak D, Mierzwińska-Nastalska E, MańkaMalara K, Kamiński T: Assessment of custom and standard self-adapted mouthguards in terms of comfort and users subjective impressions of their protective function. Dent Traumatol 2015; 31: 113-117.

8. Gawlak D, Mierzwińska-Nastalska E, MańkaMalara K, Kamiński T: Comparison of usability properties of custom-made and standard self-adapted mouthguards. Dent Traumatol 2014; 30: 306-311.

9. Mizuhashi F, Koide K, Mizuhashi R: Influence of working model angle on the formation of a pressure-formed mouthguard. Dent Traumatol 2017; 33: 189-193.

10. Takahashi M, Araie Y, Satoh Y, Iwasaki S: Influence of continuous use of a vacuum- 
forming machine for mouthguard thickness after thermoforming. Dent Traumatol 2017; 33: 188-194.

11. Mizuhashi F, Koide K, Mizuhashi R: Influence of working model angle on the formation of a pressure-formed mouthguard. Dent Traumatol 2017; 33: 189-193.

12. Takahashi M, Koide K, Satoh Y, Iwasaki S: Shape change in mouthguards sheets during thermoforming. Dent Traumatol 2016; 32: 379-384.

13. Takahashi M, Koide K, Satoh Y, Iwasaki S: Heating methods for reducing unevenness softening of mouthguard sheets in vacuumpressure formation. Dent Traumatol 2016; 32: 316-320.

14. Del Rossi G, Leyte-Vidal M: Fabricating a better mouthguard. Part I: Factors influencing mouthguard thinning. Dent Traumatol 2007; 23: 149-154.

15. Del Rossi G, Lisman P, Signorile J: Fabricating a better mouthguard. Part II: The effect of color on adaptation and fit. Dent Traumatol 2008; 24: 197-200.

16. Newsome P, Tran D, Cooke M: The role of mouthguard in the prevention of sportsrelated dental injuries: a review. Int J Paediatr Dent 2001; 11: 396-404.

17. Caesar H: Stosowanie tworzyw dentystycznych. Dental Labor 2002; 3: 48-61.

18. Gawlak D, Mańka-Malara K, MierzwińskaNastalska E, Roman G, Kamiński T, Łuniewska $M$ : A comparison of impact force reduction by polymer materials used for mouthguard fabrication. Acta Bio 2017; 19: 89-95.

19. Okoński P, Roski D, LAsek K, MierzwińskaNastalska E: Application of Biofuncional Method in prostetic rehabilitation of a patient after surgical treatment in the maxillofacial area. Protet Stomatol 2011; 4: 304-311.

20. Saini V, Singla $R$ : Biofunctional prosthetic system: a new era complete denture. J Pharm Bioallied Sci 2011; 3:170-172.
21. Gialain IO, Coto NP, Diemeier L, Noritomi $Y$, Dias RB: A three-dimensional finite element analysis of the sports mouthguard. Dent Traumatol 2016; 32: 409-415.

22. Naikmasur V, Bhargava P, Guttal K, Burde K: Soft occlusal splint therapy in the management of myofascial pain dysfunction syndrome: A follow-up study. Indian J Dent Res 2008; 19: 196-203.

23. Więckiewicz W, Predel A, WawrzyńczakGluszko M: Nieprawidłowe zastosowanie elastycznych szyn zgryzowych TMD i TMJ w początkowej terapii dysfunkcji narządu żucia powodem długotrwałego leczenia przyczynowego - opis przypadku. Protet Stomatol 2009; 5: 321-326.

24. Glass RT, Conrad RS, Wood RC, Warren AJ, Kohler GA, Bullard JW, Benson G, Gulden $J M$ : Protective athletic mouthguards: Do they cause harm? Sports Health 2009; 1: 411-415.

25. Mańka-Malara $K$, Łuniewska J, Luniewska M, Hovhannisyan A, Gawlak D: Assessment of intraoral mouthguards: usage and hygiene issues. Protet Stomatol 2017; 67: 182-196.

26. Murakami S, Maeda Y, Ghanem A, Uchiyama $Y$, Kreiborg S: Influence of mouthguard on temporomandibular joint. Medicine and Science in Sports 2008; 18: 591-595.

27. Kostrzewa-Janicka J: Siła zgryzowa a budowa morfologiczna części twarzowej czaszki u pacjentów ze schorzeniami skroniowo-żuchwowymi. Protet Stomatol 2007; 57: 316324.

28. Verissimo C, Bicalho AA, Soares PBF, Tantbirojn D, Versluis A, Doares CJ: The effect of antagonist tooth contact on the biomechanical response of custom-fitted mouthguards. Dent Traumatol 2017; 33: 5763.

Zaakceptowano do druku: 7.07.2019 r.

Adres autorów: 02-091 Warszawa, Binieckiego 6.

(c) Zarząd Główny PTS 2020 r. 